\title{
Localized disruption of Narp in medial prefrontal cortex blocks reinforcer devaluation performance
}

\author{
Alexander W. Johnson, ${ }^{1,2,6}$ Sungho Han, ${ }^{3}$ Ashley M. Blouin, ${ }^{3}$ Jasjit Saini, ${ }^{4}$ Paul F. Worley, ${ }^{4}$ \\ Matthew J. During, ${ }^{5}$ Peter C. Holland, ${ }^{1,4}$ Jay M. Baraban, ${ }^{3,4}$ and Irving M. Reti ${ }^{3,4}$ \\ ${ }^{1}$ Department of Psychological and Brain Sciences, Johns Hopkins University, Baltimore, Maryland 21218, USA; ${ }^{2}$ Neurogenetics and \\ Behavior Center, Johns Hopkins University, Baltimore, Maryland 21218, USA; ${ }^{3}$ Department of Psychiatry and Behavioral Sciences, \\ Johns Hopkins School of Medicine, Baltimore, Maryland 21218, USA; ${ }^{4}$ Solomon Snyder Department of Neuroscience, Johns Hopkins \\ School of Medicine, Baltimore, Maryland 21218, USA; ${ }^{5}$ Department of Molecular Virology, Ohio State University, Columbus, Ohio \\ 43210, USA
}

\begin{abstract}
Neuronal activity regulated pentraxin (Narp) is a secreted protein that regulates $\alpha$-amino-3-hydroxyl-5-methyl-4-isoxazolepropionate receptors (AMPAR) aggregation and synaptogenesis. Mapping of Narp-positive neurons in brain has revealed it is prominently expressed in several limbic system projection pathways. Consistent with this localization pattern, Narp knockout mice show deficits in using the current value of a reinforcer to guide behavior, a critical function of the limbic system. To help assess whether this behavioral deficit is due to impairment of synaptogenesis during development or in modulating synaptic signaling in the mature brain, we have used a dominant negative Narp viral construct which blocks trafficking of endogenous Narp to axons. Focal injection of this viral construct into the medial prefrontal cortex (mPFC) of adult mice, a region containing Narp-positive projection neurons, blocked reinforcer devaluation. Thus, these results indicate that Narp released from mPFC neurons plays a key role in mediating synaptic changes underlying instrumental reinforcer devaluation.
\end{abstract}

[Supplemental material is available online at http://www.learnmem.org.]

Neuronal activity regulated pentraxin (Narp) is an immediate early gene product that is induced in neurons in response to synaptic activity (Tsui et al. 1996). This pentraxin is a secreted protein that binds to the extracellular surface of $\alpha$-amino-3-hydroxyl-5methyl-4-isoxazole-propionate receptors (AMPARs) and has been implicated in regulating AMPA receptor clustering and trafficking (O'Brien et al. 1999; Xu et al. 2003). In contrast to the nearly ubiquitous expression of AMPAR among neurons of the central nervous system, Narp expression in brain is markedly heterogenous with prominent expression in several limbic system pathways (Tsui et al. 1996; Lu et al. 2002; Reti et al. 2002a,b). Consistent with its selective localization in limbic system circuits, Narp knockout mice $(\mathrm{KO})$ show enhanced locomotor responses to cocaine (Pacchioni et al. 2009), delayed extinction of morphineinduced conditioned place preference (Crombag et al. 2009), and deficits in reward learning (Johnson et al. 2007). In this latter study, instrumental responding of Narp KO mice was insensitive to post-conditioning changes in reinforcer value (i.e., reinforcer devaluation) (Johnson et al. 2007).

Narp is constitutively expressed in regions of reward circuitry that are necessary for normal devaluation performance. For example, Narp-positive neuronal cell bodies are located in the medial prefrontal cortex (mPFC) and basolateral amygdala (BLA), while the nucleus accumbens core (ACBC) contains a plexus of Narppositive axons and presumed terminals but lacks Narp-positive cell bodies (Corbit et al. 2001; Lu et al. 2002; Ostlund and Balleine 2005; Johnson et al. 2009). Thus, Narp located in these regions could mediate normal reinforcer devaluation performance.

${ }^{6}$ Corresponding author.

E-mail awj@jhu.edu; fax (410) 516-0494.

Article is online at http://www.learnmem.org/cgi/doi/10.1101//m.1937210.
However, since Narp plays a key role in synaptogenesis during circuit development (Koch and Ullian 2010) and may also mediate alterations in AMPAR trafficking that underlie synaptic plasticity in mature circuits, it is unclear whether the deficits in reward learning found in Narp KO mice are due to the absence of Narp during or after limbic circuit development. Furthermore, it is currently unclear which Narp-positive reward-circuit pathways mediate the reinforcer devaluation impairment seen in Narp KO mice (Johnson et al. 2007).

To help address these questions, we focused on testing the role of Narp-positive neurons in the mPFC with this paradigm. First, we ascertained that Narp-positive neurons located in the mPFC are projection neurons that are part of previously characterized limbic circuitry. To this end, we used retrograde tracing from the nucleus accumbens to check if Narp neurons in mPFC project to this region, a known target of mPFC projection neurons. Second, we assessed the impact of blocking Narp function in these mPFC neurons in adult mice on reinforcer devaluation. Mice were treated with a dominant-negative form of Narp (NarpN) that selectively binds to endogenous Narp and has been shown to prevent its trafficking into axons, block its secretion, and inhibit its ability to induce AMPAR aggregation ( $\mathrm{O}^{\prime}$ Brien et al. 2002).

\section{Results}

\section{Experiment 1}

It is well-established that the mPFC sends major projections to several other limbic regions including the nucleus accumbens (Sesack et al. 1989). Accordingly, to assess whether Narp-positive neurons located in the mPFC contribute to these limbic projections, we checked whether Narp-positive neurons are labeled by 
a retrograde tracer injected into the nucleus accumbens. We chose this area for injection of retrograde tracer since we had noted in previous studies mapping Narp localization in the limbic system that it contained a plexus of Narp axonal processes (Fig. 1A-E). To check the specificity of Narp axonal staining in the nucleus accumbens, we confirmed that this staining is absent in mice harboring deletions of all three neuronal pentraxins $\left(F_{(1,4)}=53.73\right.$, $P=0.001$ ).

To label mPFC neurons that project to the nucleus accumbens, the retrograde tracer cholera toxin subunit b $(\mathrm{CTb})$ was delivered by iontophoresis into this nucleus. mPFC sections were then processed for dual-labeling immunohistochemistry for both Narp and CTb. In C57BL/6J (C57) mice, Narp-positive neurons are present in both infralimbic (IL) and prelimbic (PL) cortices. With increased magnification of mPFC cells, it was evident that almost all (>95\%) Narp-positive neurons in these regions (Fig. 1I) also contained $\mathrm{CTb}$ (Fig. 1J), indicating that the overwhelming majority of Narp-positive mPFC neurons project to the nucleus accumbens. Of note, there were many mPFC neurons that were stained with CTb but were Narp-negative,
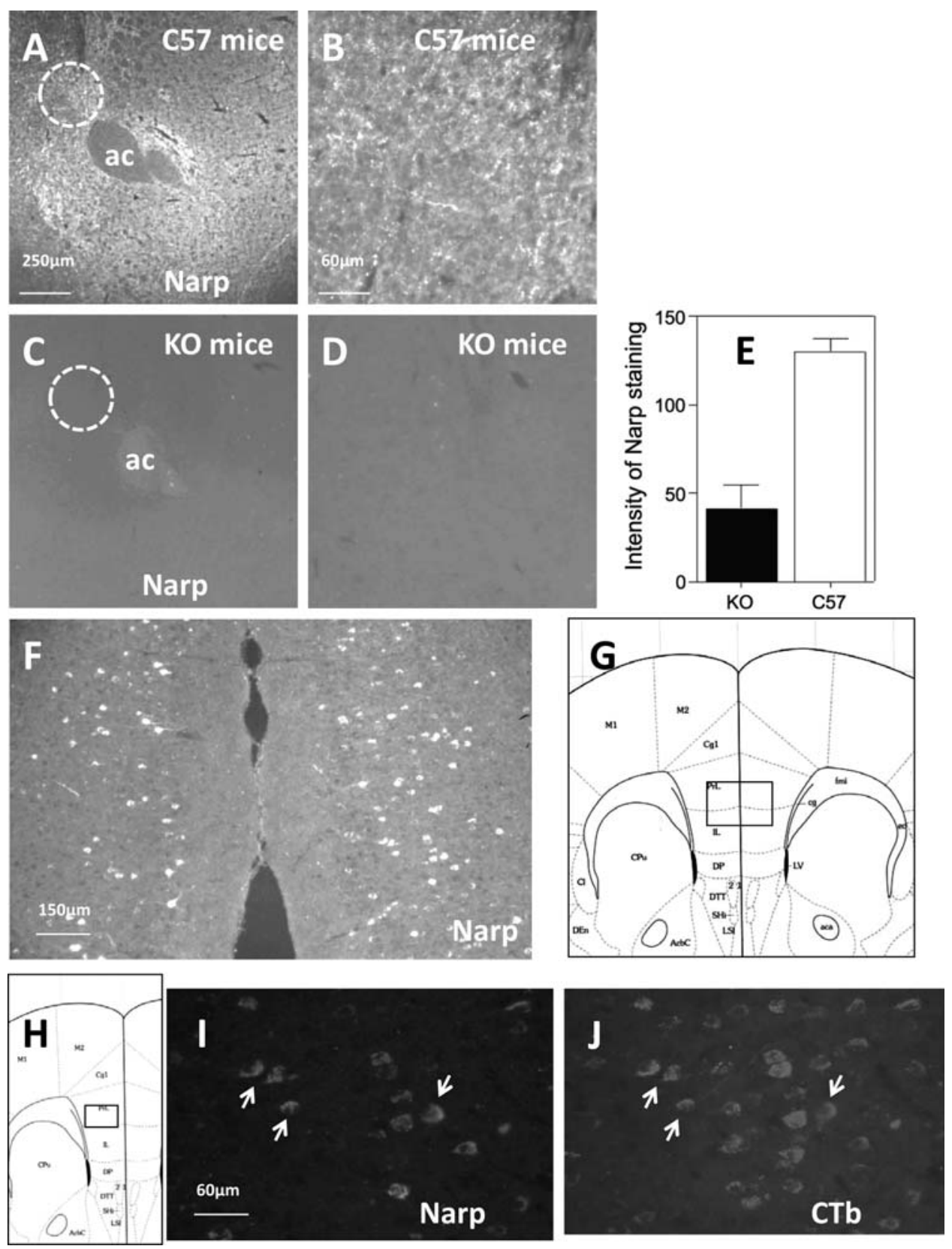

Figure 1. Narp projections from mPFC to NAc. (A) This panel shows a low power view of Narp immunostaining in the nucleus accumbens. (B) High magnification view shows discrete Narp-positive puncta. Narp staining is absent in low $(C)$ and high power $(D)$ views of corresponding areas in sections taken from mice lacking all three neuronal pentraxins including Narp. $(E)$ Intensity of Narp staining was quantified in the dorsomedial region of ACBC indicated by broken circle in wild-type $(n=3)$ and pentraxin triple KO $(n=3)$ mice. $(F)$ Narp cell body staining in mPFC. Narp-positive neurons are shown in infralimbic and prelimbic cortices of mPFC. (G) Approximate location of region shown in $F$. $(H)$ Approximate location of region shown in $I$ and $J .(I, J)$ Double labeling with Narp $(I)$ and choleratoxin b (CTb) $(J)$ shows that nearly all Narp-positive neurons are also labeled with CTb (arrows), but not vice versa. ac, anterior commissure. 
indicating that not all the accumbal afferents from the mPFC are Narp-positive. Nevertheless, these findings confirm our hypothesis that Narp-positive neurons located in the mPFC link it to other limbic nuclei.

\section{Experiment 2}

\section{Instrumental training}

In this set of studies, we assessed whether blocking the secretion of endogenous Narp expressed by mPFC neurons is sufficient to mimic the deficit in reinforcer devaluation performance observed in Narp KO mice. To this end, we injected an adeno-associated virus expressing a Narp dominant negative (AAV-NarpN) into the mPFC of 10 -wk-old C57 mice $(n=10)$. Control mice received injections of AAV-YFP $(n=10)$ also targeting the mPFC. After a two-week recovery period, instrumental training was conducted, in which mice were trained to respond on two different levers for the delivery of discriminatively different reinforcers (orangeand grape-flavored sucrose). Across training sessions the cost of reinforcement was gradually increased such that, prior to test, reinforcement was delivered on a Random Ratio-10 schedule (RR-10) (i.e., on average every 10 responses resulted in reward delivery). There were no differences in instrumental acquisition between mice injected with either AAV-NarpN or AAV-YFP into the $\mathrm{mPFC}$, with all mice increasing their rate of responding as training progressed (Fig. 2A). Two-way ANOVA with between subject factor of group (NarpN or YFP) and within-subject factor of session (Sessions 1-10; averaged across reinforcers) revealed a main effect of session only $\left(F_{(9,162)}=50.04, P<0.001\right)$. Importantly, there was no effect of group, or interaction between the variables $\left(F^{\prime} \mathrm{s}<1 ; P^{\prime} \mathrm{s}>0.83\right)$.

\section{Reinforcer devaluation test}

Following training mice received two reinforcer devaluation tests, one with each reinforcer conducted on separate days, with each

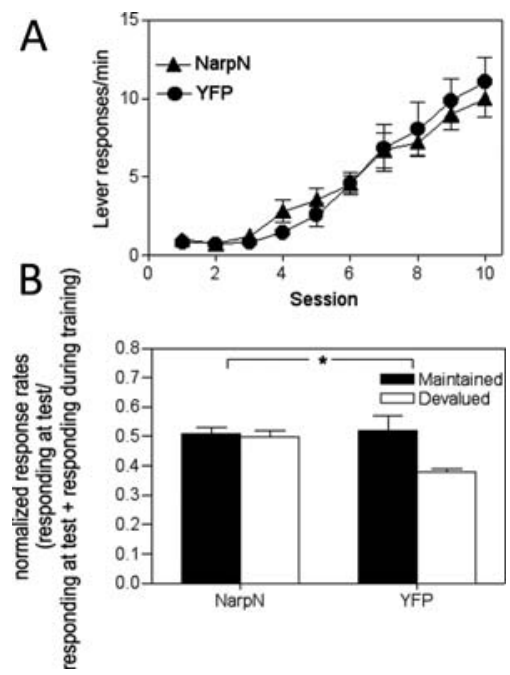

Figure 2. Instrumental training and reinforcer devaluation following mPFC injections of AAV-YFP or NarpN in mPFC. $(A)$ Mean lever response rates averaged across grape- and orange-paired levers in AAV-, YFP(circles; $n=10$ ), and NarpN-injected mice (triangles; $n=10$ ) during instrumental training. $(B)$ Devaluation extinction test results following satiety treatment on lever associated with maintained (closed bars) and devalued reinforcer (open bars) in AAV-NarpN- and AAV-YFP-treated mice. Test data were normalized to training response rates (Responding at Test/Responding at Test + Responding During Final Acquisition Session). Error bars indicate standard error of the mean. *Significant group $\times$ response interaction; $P=0.01$. test separated by three instrumental retraining sessions. Devaluation of the reinforcer was accomplished by prefeeding one of the two reinforcers for a 2-h period prior to the test. This sensory-specific satiety treatment served to devalue the reinforcer in a context outside the testing environment (individual cage setting), while maintaining the value of the non-prefed reinforcer. Immediately following this devaluation treatment, mice were placed back into the experimental chambers, where both levers were presented. The test was conducted under no reward (i.e., extinction) conditions. To compensate for individual preferences for a particular lever or reinforcer, test performance was normalized to performance on the last day of acquisition by using the formula: Responding During the Test/Responding During Test + Responding on the Last Day of Acquisition. These scores were then averaged for the two devaluation tests (Fig. 2B). YFP mice showed a devaluation effect, that is, suppression of devalued lever responding relative to maintained lever responding. However, devaluation of the reinforcer failed to influence test response rates in dominant-negative treated mice. ANOVA with variables of group $\times$ response (devalued, maintained) revealed no main effect of group $\left(F_{(1,18)}=1.86, P=0.19\right)$, a significant effect of response $\left(F_{(1,18)}=8.00, P=0.01\right)$, and a significant interaction between the variables $\left(F_{(1,18)}=7.11, P=0.01\right)$. Post-hoc Tukey HSD tests revealed a significant devaluation effect in YFP $(P<0.01)$ but not NarpN-treated mice $(P=0.99)$. These results show that dominant-negative knockdown of Narp in mPFC neurons resulted in a deficit in reinforcer devaluation.

Neither the number of magazine entries (YFP $=8.35 \pm 1.55$; NarpN $=11.25 \pm 1.76$ ) nor locomotor activity scores (YFP $=$ $566.4 \pm 102$ activity units; $\mathrm{NarpN}=756 \pm 160$ ) during the two devaluation tests differed between the groups; $F \mathrm{~s}<1.51$; $P$ 's $>$ 0.23. Thus, Narp knockdown's effects were specific to goaldirected lever-press behavior.

\section{Reinforcer choice test}

To confirm that the deficit in NarpN mice was not due to a failure of the devaluation treatment to influence the value of the reinforcer itself, or an inability to discriminate between the grape and orange reinforcers, choice tests following separate devaluation of each reinforcer were administered. In separate sessions, each reinforcer was devalued by prefeeding as detailed previously, followed by a 30-min choice test where each reinforcer was available to the mice in the individual cages. During this reinforcer choice test, the mean consumption of each reinforcer was similar for both groups, with both YFP and NarpN consuming less of the devalued reinforcer $(\mathrm{YFP}=0.65 \pm 0.14 \mathrm{~g}$; NarpN $=0.83 \pm 0.13 \mathrm{~g}$ ) than of the maintained reinforcer (YFP $=1.25 \pm 0.17 \mathrm{~g}$; $\operatorname{NarpN}=1.14 \pm 0.16 \mathrm{~g}$ ). This assertion was supported by ANOVA, which revealed a main effect of reinforcer only $\left(F_{(1,18)}=10.27, P<0.01\right)$, with no differences between the groups $(F<1)$ nor interactions $\left(F_{(1,18)}=1.09, P=0.31\right)$.

\section{Histological evaluation of mPFC viral injections}

To assess the extent of viral infection in the mice that underwent behavioral testing, we processed mPFC sections from AAV-NarpN and AAV-YFP mice for either myc immunostaining (the NarpN construct contains a myc epitope tag) or direct visualization of YFP fluorescence, respectively. We found that a similar percentage of cells $(\sim 70 \%)$ in mPFC were infected following either treatment (Fig. 3A-D), as revealed by one-way ANOVA $(F<1)$.

As our retrograde tracing studies indicate that the nucleus accumbens receives Narp-positive afferents from other limbic areas, such as the BLA (Reti et al. 2008c), it was unclear whether the mPFC injections of AAV-NarpN would produce a substantial 
reduction in the intensity of endogenous Narp staining in the nucleus accumbens. To assess this possibility we also processed nucleus accumbens sections from the AAV-NarpN and AAV-YFP mice for Narp immunostaining. Examination of these sections indicated that mPFC injections of AAV-NarpN produced a partial reduction of endogenous Narp in the ACBC compared with AAV-YFP mice (Fig. 3E,F). To quantify these changes, we focused first on the dorsomedial region of ACBc (Fig. 3G), which has been shown to receive afferents from IL and PL regions of $\mathrm{mPFC}$ (Sesack et al. 1989; Moussawi et al. 2009). One-way ANOVA indicated a trend toward decreased Narp staining in AAV-NarpN mice in this portion of the nucleus accumbens $\left(F_{(1,15)}=4.11, P=0.06\right)$. Furthermore, we examined the ventrolateral ACBc (Fig. 3H), which revealed no significant differences in endogenous Narp $\left(F_{(1,15)}=1.49, P=0.24\right)$ between YFP and NarpN mice. Finally, we examined the nucleus accumbens shell, which also revealed no differences in Narp immunostaining between the groups $(F<1$; Fig. 3I).

\section{Discussion}

Using a dominant-negative approach we identified a critical role for mPFC Narp-positive projections in reinforcer devaluation. In a previous study, we found instrumental responding of Narp KO mice to be insensitive to current outcome value (Johnson et al. 2007). However, that initial study did not address which populations of Narp neurons mediate this response and whether the deficit in limbic system function observed in Narp KO mice reflects its absence during development or following brain maturation. Here, we demonstrate that disrupting Narp function in the mPFC in young adult mice mimics the deficit previously observed in mice with a global deficiency in Narp. Accordingly, these findings indicate that Narp secreted by MPFC neurons in mature mice is critical in mediating reinforcer devaluation.

The failure in NarpN mice was not due to any gross behavioral impairments resulting from dominant-negative treatment, as all mice showed similar rates of instrumental acquisition. Moreover, the deficits in NarpN mice could not be accounted for by a simple failure in reinforcer discrimination as both groups showed reduced consumption of the devalued food. Nor could the impairments in the dominant-negative group be attributable to nonspecific motoric actions of the viral approach, as there were no changes in other response measures that might be expected to be sensitive to motor deficits, including locomotor activity and food cup entries. Thus, the impairment in dominant-negative treated mice suggests Narp plays a role in one or more processes
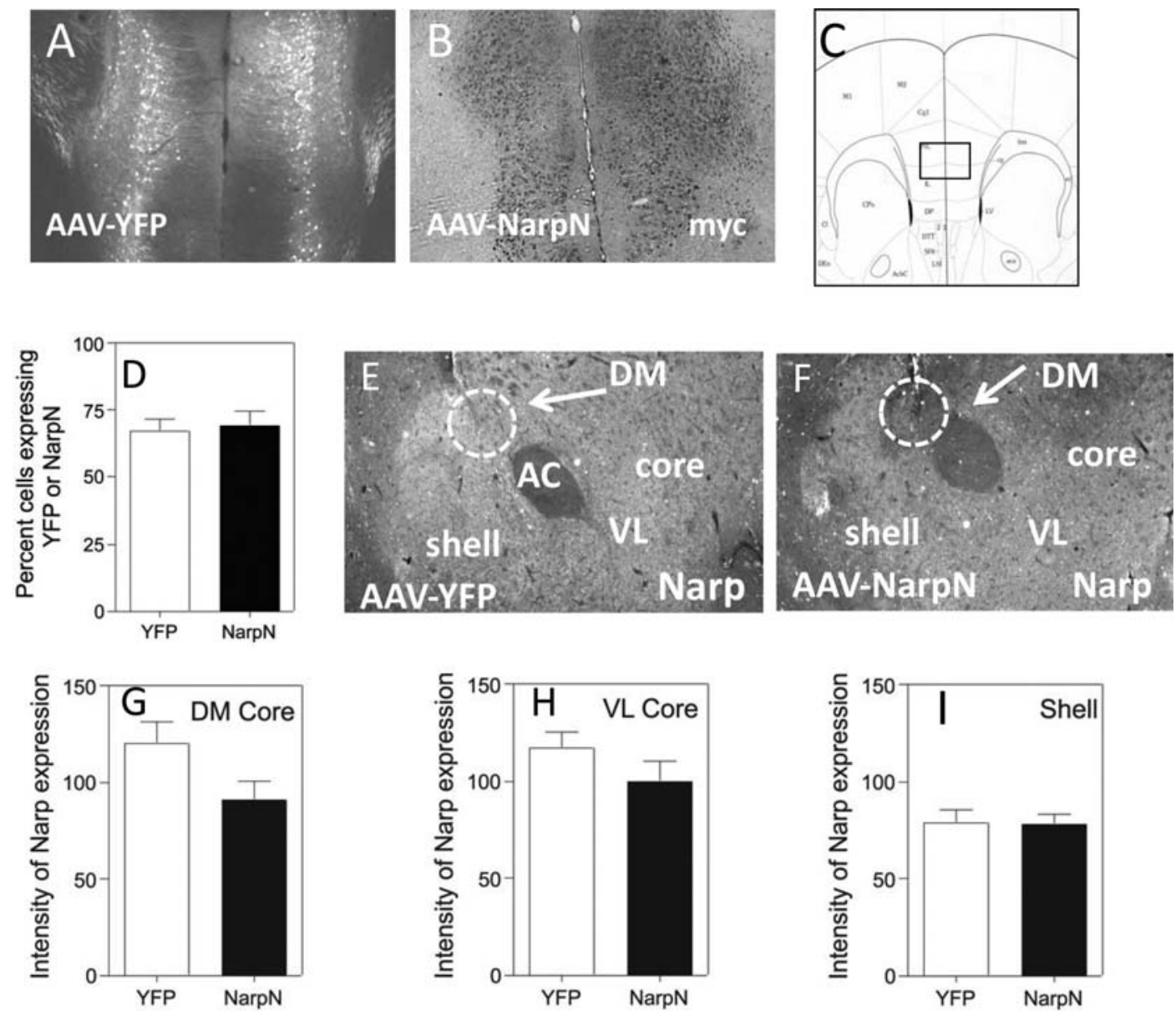

Figure 3. Histological evaluation of mPFC and accumbens following viral injections in mPFC. Photomicrographs of $(A)$ YFP and $(B)$ myc expression in mPFC. (C) Approximate location of region shown in $A$ and $B$. (D) Stereological analysis of percent of mPFC neurons expressing either YFP or myc-tagged NarpN construct. Photomicrographs of Narp expression in ACBC following mPFC injection of (E) AAV-YFP or (F) AAV-NarpN. (G-I) Intensity of Narp staining in $(G)$ dorsomedial ACBC (regions enclosed by dotted circles), $(H)$ ventrolateral ACBC, and $(I)$ nucleus accumbens shell, following AAV-YFP or NarpN $\mathrm{mPFC}$ injections. Error bars indicate standard error of the mean. ac, anterior commissure; DM, dorsomedial accumbens core; VL, ventrolateral accumbens core; shell, accumbens shell. 
that are pertinent to devaluation including: associating the specific features of the reinforcers with the relevant lever; updating these representations following post-training reductions in outcome value; and/or using the updated representations to guide appropriate instrumental performance.

In the retrograde tracing study we found that the overwhelming majority of Narp-positive neurons in the mPFC project to the nucleus accumbens. As mPFC neurons have been shown to project to the ACBc (Sesack et al. 1989) and this subregion of the nucleus accumbens has been implicated in mediating reinforcer devaluation performance (Corbit et al. 2001), our results support the assertion that Narp neurons that project from the mPFC to the $\mathrm{ACBc}$ may play a role in reinforcer devaluation. However, that inference must be viewed with considerable caution. First, we revealed only a trend toward dorsomedial ACBc suppression of endogenous Narp in dominant-negative treated mice. Second, Narp neurons from the mPFC may also project to other limbic regions that have been implicated in mediating devaluation including the BLA, medial dorsal striatum, and thalamus (McFarlan and Haber 2002; Sah et al. 2003; Yin et al. 2005; Mitchell et al. 2007; Johnson et al. 2009; Shiflett and Balleine 2009). Of note, preliminary findings from our laboratory suggest Narp-positive neurons in the mPFC also project to BLA (A Blouin, S Han, JM Baraban, IM Reti, unpubl. data); therefore, suppression of Narp secretion in target areas outside of the $\mathrm{ACBC}$ might underlie the observed impairment in reinforcer devaluation.

Studies conducted in neuronal culture systems have implicated Narp in regulating AMPAR trafficking (O'Brien et al. 1999; $\mathrm{Xu}$ et al. 2003). Consistent with these in vitro findings, Narp KO mice show a defect in AMPA response sensitization in the accumbens following cocaine pretreatment (Pacchioni et al. 2009), suggesting that Narp exerts a similar function in vivo. Thus, our findings suggest that NarpN injections into the mPFC interfere with the ability of endogenous Narp normally released from mPFC neurons to modulate AMPAR trafficking at their synaptic contacts and thereby disrupted reinforcer devaluation. This model of Narp action is consistent with the observation that AMPAR GluR1 subunit KO mice also show devaluation impairments (Johnson et al. 2005).

Previous characterization of the NarpN dominant-negative construct has demonstrated that it acts with a high degree of selectivity, as it does not affect secretion or surface expression of NP1 (O'Brien et al. 2002). Furthermore, we have confirmed that infection of neurons with AAV-NarpN both in vitro and in vivo selectively affects Narp, but not other neuronal pentraxins (Supplemental Data). In cortical cultures, AAV-NarpN infection produces nearly total loss of surface expression of Narp, without significantly affecting surface NP1 staining. Injection of AAVNarpN into the hippocampus produces selective loss of Narp immunostaining in the neuropil of the dentate hilus, without reducing staining for either NP1 or NPR. However, we did note a small increase in cell body staining of NP1 and NPR in dentate granule cells following AAV-NarpN injection into the hippocampus (Supplemental Fig. 2). Thus, NarpN may also produce a slight retention of these neuronal pentraxins in cell bodies via a direct interaction with them or, alternatively, this may reflect changes in NP1 and NPR expression or trafficking that occur in response to the more prominent disruption of Narp trafficking caused by NarpN. As NP1 and NPR are also expressed in cortical neurons (Schlimgen et al. 1995; Dodds et al. 1997), it would be interesting in future studies to examine whether knockdown or deletion of these other neuronal pentraxin family members in the mPFC affects reward devaluation.

In sum, our studies demonstrate that Narp expressed in neurons in the mPFC plays a critical role in outcome-mediated behavioral control. Narp expression is induced during drug withdrawal from a range of psychoactive substances including morphine, nicotine, and $\Delta^{9}$-tetrahydrocannabinol (Reti and Baraban 2003; Reti et al. 2009). Narp has also been shown to influence locomotor responses to cocaine (Pacchioni et al. 2009) and mediate extinction of morphine place preference conditioning (Crombag et al. 2009). Thus this pentraxin may regulate plasticity processes underlying drug addiction (Reti et al. 2008a,b). It is noteworthy that a characteristic feature of drug addiction (American Psychiatric Association 2000) concerns the "individual's failure to abstain from using the substance despite having evidence of the difficulty it is causing." This form of compulsive drug taking may in part be mediated by aberrant devaluation processes, where the addict's behavior is driven by habitual rather than goaldirected processes (Tiffany 1990). Narp signaling pathways may be responsible for such drug-mediated deficits in behavioral control.

\section{Materials and Methods}

\section{Subjects}

For immunohistochemical studies we used C57 mice from the National Cancer Institute (NCI) $(n=3)$ and neuronal pentraxin triple knockout mice $(n=3)$ which lack all three neuronal pentraxins: Narp, NP1, and NPR (Bjartmar et al. 2006). Male mice were used for these studies at approximately 3 mo of age.

Behavioral testing was conducted in male C57 strain mice $(n=20)$, purchased from NCI. Viral injections into the mPFC were performed at the Johns Hopkins University School of Medicine when they were approximately $10 \mathrm{wk}$ of age. Three weeks following surgery, mice were transferred to the Neurogenetics and Behavior Center (NBC), Johns Hopkins University, and housed in groups of two per cage under a 12-h-light/dark cycle (lights on 7:00-19:00). Mice were handled daily for one week prior to undergoing food deprivation for $3 \mathrm{~d}$, followed by behavioral testing. During this period of food deprivation mice were restricted to a single daily meal, a procedure which resulted in weight reduction to $90 \%-95 \%$ of their ad libitum body weight. Handling and behavioral testing occurred within the light cycle between 9:00 and 17:00. All experimental procedures were approved by the Johns Hopkins University Institutional Animal Care and Use Committee.

\section{Immunohistochemical studies}

For retrograde tracing studies, CTb (List Biological) was delivered by iontophoresis ( $2 \mathrm{uA}$ over $15 \mathrm{~min}$ ) to nucleus accumbens at coordinates: AP: $+1.1 \mathrm{~mm}$, ML: $\pm 0.9 \mathrm{~mm}$, DV: $-3.9 \mathrm{~mm}$. Immunohistochemistry was performed as described previously (Reti et al. 2008a,b). Primary antibodies were used at the following dilutions: Rabbit anti-Narp (1:1500), mouse anti-myc (1:1000; Invitrogen), goat anti-CTb (1:1000; List Biological). Previous studies (as well as Supplementary Data) have demonstrated that the pattern of Narp immunostaining in the brain is distinct from that produced by NP1 and NPR antibodies, indicating that Narp antibodies do not cross-react with other neuronal pentraxins (Reti et al. 2002a; Cho et al. 2008). Sections were taken between AP: +1.0 and AP: +1.2 and analyzed using NIH Image J software to assess the intensity of Narp staining in nucleus accumbens.

\section{Viral vector injections into the $\mathrm{mPFC}$}

To suppress Narp expression, 10-wk-old C57 mice were treated with an adeno-associated virus expressing a Narp dominant negative (AAV-NarpN) with mutations of Narp at the C terminus $(n=10)$. To control for nonspecific effects of viral injection, we conducted parallel studies with AAV-YFP $(n=10)$. In preliminary studies (see Supplementary Data), we confirmed that infection of cortical cultures with AAV-NarpN produces nearly complete loss of surface Narp as determined by both immunostaining and 
biotinylation studies (Supplemental Fig. 1). Furthermore, as Narp is prominently expressed in dentate gyrus mossy fibers, we checked that injection of AAV-NarpN into the dentate gyrus produces a marked reduction in Narp staining normally present in the hilar region. As NP1 and NPR are also expressed in dentate gyrus granule cells and mossy fiber axons, we were able to confirm the selectivity of AAV-NarpN in vivo as it did not reduce the intensity of NP1 or NPR staining in the dentate hilus in adjacent sections (Supplemental Fig. 2). Descriptions of the viral vector construct, its packaging and testing are provided in the Supplementary Methods and Data sections.

Animals were anesthetized with a combination of ketamine, $80 \mathrm{mg} / \mathrm{kg}$, and xylazine, $12 \mathrm{mg} / \mathrm{kg}$, injected ip. Two AAV-NarpN injections were needed bilaterally to adequately cover the entire extent of the mPFC region. One injection targeted the PL cortex and the other the IL cortex. Co-ordinates for injections (Franklin and Paxinos 1997) were: AP: $+2.7 \mathrm{~mm}, \mathrm{ML}: \pm 0.4 \mathrm{~mm}$, DV: $-1.5 \mathrm{~mm}$ and AP: $+1.9 \mathrm{~mm}, \mathrm{ML}: \pm 0.4 \mathrm{~mm}, \mathrm{DV}:-2.5 \mathrm{~mm}$, respectively. The volume of each injection was $1 \mu \mathrm{L}$ and fluid was infused over 10 min using a KDS model 1000 pump. The needle was withdrawn $3 \mathrm{~min}$ after the end of the infusion. Animals were kept in regular housing post-surgery; no special precautions were required as the viral vector is replication deficient. For $2 \mathrm{wk}$ until they healed, animals were housed singly. After 2 wk, two animals were combined per cage. A few days later they were transferred to the Neurogenetics and Behavior Center (John Hopkins University) for behavioral testing. Following the completion of behavioral testing mice were sacrificed and immunohistochemistry was performed as described previously (Reti et al. 2008a,b). Two mice (one YFP and NarpN) died prior to being sacrificed. In addition, immunostaining for Narp in the ventral striatum failed for one YFP mouse.

\section{Behavioral apparatus and methods}

Experimental chambers consisted of aluminum front and back walls, clear polycarbonate sides and ceiling, and floor comprised of parallel, stainless-steel rods, all housed in sound-attenuating shells (Med Associates). Chambers were modified to include a programmable food cup into which $50 \mu \mathrm{L}$ of liquid reward could be delivered. Food cups were connected to vacuums, allowing for the removal of liquid when desired. Infrared photocells installed in the food cup monitored the time spent and number of entries into the cup. Within each chamber, retractable ultra-sensitive mouse levers (Med Associates) were available to the right and left sides of the food cup. Ambient light was supplied by a $28 \mathrm{~V}$, $100 \mathrm{~mA}$ house light mounted inside the sound attenuating shell. An IBM-compatible computer, with Med PC Software, controlled the apparatus and recorded data. For the reinforcer devaluation test stage, individual cages were setup to include two cubes, positioned at opposite sides of the cage. Each cube was capable of holding $5 \mathrm{~mL}$ of liquid.

For reinforcer devaluation, mice were assigned to one of the eight experimental chambers, and thereafter trained in that chamber. Initially all mice received one session of food cup training each day for a total of two days. For one session mice received food cup training with $50-\mu \mathrm{L}$ deliveries of orange-flavored sucrose solution ("orange") and in the other session 50- $\mu \mathrm{L}$ deliveries of grape-flavored sucrose solution ("grape"). The order of the two sessions was counterbalanced. The solutions were $0.1 \%$ Kool-Aid brand flavorings in 5\% sucrose $(\mathrm{w} / \mathrm{v})$. During food cup training, reinforcement was delivered on a random-time $30 \mathrm{sec}$ schedule (RT $30 \mathrm{sec}$ ) and continued until 60 reinforcers had been delivered.

Mice then received two instrumental training sessions per day, separated by approximately $2 \mathrm{~h}$, one with only the left lever present and one with only the right lever present, with the order of the two sessions alternating daily. For half the mice in each group, responses on the left lever resulted in grape delivery, whereas right lever responses produced delivery of orange. The remaining mice received the opposite response-outcome contingencies. Initially mice received three 30-min sessions on each lever where reinforcement was delivered following each lever press (fixed-response 1). Next, mice received four sessions on a
RR-5 schedule. For the final three sessions reinforcement was delivered on a RR-10 schedule. Thirty minutes prior to each of these final sessions, mice were acclimatized to the cages that would subsequently be used to devalue the reinforcer. In total, mice received 10 sessions of instrumental training on each lever prior to the initial test.

The next day, mice received sensory-specific devaluation treatment by prefeeding each mouse with one of the two outcomes for a 2-h period. Each mouse was placed in a separate cage, with a cube filled with $5 \mathrm{~mL}$ of either grape or orange, fully counterbalanced across the prior response-outcome contingencies. The experimenter closely monitored and recorded reinforcer consumption during this phase. As the solution was consumed, it was replaced in 1-mL increments to ensure continuous reward availability for each mouse.

Immediately following the devaluation treatment, the mice were given a 10-min extinction test session in the experimental chamber during which responses were not reinforced with reward delivery. Unlike in training, both levers were available in this test session. To the extent that responding was controlled by the current value of the reward anticipated after each of the two responses (left and right lever presses), mice would preferentially perform the response that previously had been reinforced with the reward that had not been prefed (i.e., the maintained response).

Finally, the effectiveness of the prefeeding devaluation treatment in altering the mice's preference for the rewards themselves was assessed. On completion of prefeeding identical to that used previously, the mice were given access to two cubes, one containing $5 \mathrm{~mL}$ of the prefed reinforcer and the other containing $5 \mathrm{~mL}$ of the other reinforcer (reinforcer choice test). Mice were given 30 min to consume each reward, with the expectation that consumption would be greater for the maintained reward.

On completion of this test, on separate days mice received three sessions of instrumental retraining on a RR-10 schedule. All mice then received devaluation treatment with the other reinforcer (i.e., previously maintained reinforcer), followed by a 10min extinction test session of lever pressing in the experimental chamber. Finally, all mice received a reinforcer choice test following devaluation of this reinforcer. Thus, mice received devaluation and reinforcer choice tests under conditions where each reinforcer was separately devalued.

Following completion of behavioral testing, mice were euthanized and brains were processed for histology. To evaluate the location and extent of AAV-NarpN and AAV-YFP viral infections, mPFC sections were either stained with myc antibodies to detect the NarpN construct which contains a C-terminal tag (Supplemental Fig. 1) or viewed by fluorescent microscopy to visualize YFP expression. Nucleus accumbens sections were processed for Narp immunostaining to evaluate the effect of viral injections on Narp axons and terminals in this region.

\section{Acknowledgments}

We thank Dr. Qun Li for assistance with iontophoresis. This study was supported by RO1 DA16303 (I.M.R.).

\section{References}

American Psychiatric Association. 2000. Diagnostic and statistical manual of mental disorders, 4th ed. pp. 175-194.

Bjartmar L, Huberman AD, Ullian EM, Renteria RC, Liu XQ, Xu WF, Prezioso J, Susman MW, Stellwagen D, Stokes CC, et al. 2006. Neuronal pentraxins mediate synaptic refinement in the developing visual system. J Neurosci 26: 6269-6281.

Cho RW, Park JM, Wolff SBE, Xu D, Hopf C, Kim JA, Reddy RC, Petralia RS, Perin MS, Linden DJ, et al. 2008. mGluR1/5-Dependent long-term depression requires the regulated ectodomain cleavage of neuronal pentraxin NPR by TACE. Neuron 57: 858-871.

Corbit LH, Muir JL, Balleine BW. 2001. The role of the nucleus accumbens in instrumental conditioning: Evidence of a functional dissociation between accumbens core and shell. J Neurosci 21: 3251-3260.

Crombag HS, Dickson M, Dinenna M, Johnson AW, Perin MS, Holland PC, Baraban JM, Reti IM. 2009. Narp deletion blocks extinction of 
morphine place preference conditioning. Neuropsychopharmacology 34: $857-866$.

Dodds DC, Omeis IA, Cushman SJ, Helms JA, Perin MS. 1997. Neuronal pentraxin receptor, a novel putative integral membrane pentraxin that interacts with neuronal pentraxin 1 and 2 and taipoxin-associated calcium-binding protein 49. J Biol Chem 272: 21488-21494.

Franklin KBJ, Paxinos G. 1997. The mouse brain in stereotaxic coordinates, 1st ed. Academic Press, NY.

Johnson AW, Bannerman DM, Rawlins NP, Sprengel R, Good MA. 2005. Impaired outcome-specific devaluation of instrumental responding in mice with a targeted deletion of the AMPA receptor glutamate receptor 1 subunit. J Neurosci 25: 2359-2365.

Johnson AW, Crombag HS, Takamiya K, Baraban JM, Holland PC, Huganir RL, Reti IM. 2007. A selective role for neuronal activity regulated pentraxin in the processing of sensory-specific incentive value. J Neurosci 27: 13430-13435.

Johnson AW, Gallagher M, Holland PC. 2009. The basolateral amygdala is critical to the expression of pavlovian and instrumental outcomespecific reinforcer devaluation effects. J Neurosci 29: 696-704.

Koch SM, Ullian EM. 2010. Neuronal pentraxins mediate silent synapse conversion in the developing visual system. J Neurosci 14: 5404-5414.

Lu W, Marinelli M, Xu D, Worley PF, Wolf ME. 2002. Amphetamine and cocaine do not increase Narp expression in rat ventral tegmental area, nucleus accumbens or prefrontal cortex, but Narp may contribute to individual differences in responding to a novel environment. Eur J Neurosci 15: 2027-2036.

McFarland NR, Haber SN. 2002. Thalamic relay nuclei of the basal ganglia form both reciprocal and nonreciprocal cortical connections, linking multiple frontal cortical areas. J Neurosci 22: 8117-8132.

Mitchell AS, Browning PGF, Baxter MG. 2007. Neurotoxic lesions of the medial mediodorsal nucleus of the thalamus disrupt reinforcer devaluation effects in rhesus monkeys. J Neurosci 27: 11289-11295.

Moussawi K, Pacchioni A, Moran M, Olive MF, Gass JT, Lavin A, Kalivas PW. 2009. N-Acetylcysteine reverses cocaine-induced metaplasticity. Nat Neurosci 12: 182-189.

O'Brien R, Xu DS, Mi RF, Tang XP, Hopf C, Worley P. 2002. Synaptically targeted Narp plays an essential role in the aggregation of AMPA receptors at excitatory synapses in cultured spinal neurons. J Neurosci 22: $4487-4498$

O'Brien RJ, Xu DS, Petralia RS, Steward O, Huganir RL, Worley P. 1999. Synaptic clustering of AMPA receptors by the extracellular immediate-early gene product Narp. Neuron 23: 309-323.

Ostlund SB, Balleine BW. 2005. Lesions of medial prefrontal cortex disrupt the acquisition but not the expression of goal-directed learning. J Neurosci 25: 7763-7770.

Pacchioni AM, Vallone J, Worley PF, Kalivas PW. 2009. Neuronal pentraxins modulate cocaine-induced neuroadaptations. J Pharmacol Exp Ther 328: $183-192$.

Reti IM, Baraban JM. 2003. Opiate withdrawal induces Narp in the extended amygdala. Neuropsychopharmacology 28: 1606-1613.
Reti IM, Reddy R, Worley PF, Baraban JM. 2002a. Selective expression of Narp, a secreted neuronal pentraxin, in orexin neurons. J Neurochem 82: $1561-1565$

Reti IM, Reddy R, Worley PF, Baraban JM. 2002b. Prominent Narp expression in projection pathways and terminal fields. J Neurochem 82: $935-944$.

Reti IM, Crombag HS, Takamiya K, Sutton JM, Guo N, Dinenna ML, Huganir RL, Holland PC, Baraban JM. 2008a. Narp regulates longterm aversive effects of morphine withdrawal. Behav Neurosci 122: $760-768$.

Reti IM, Miskimon M, Dickson M, Petralia RS, Takamiya K, Bland R, Saini J, During MJ, Huganir RL, Baraban JM. 2008b. Activity-dependent secretion of neuronal activity regulated pentraxin from vasopressin neurons into the systemic circulation. Neuroscience 151: 352-360.

Reti IM, Johnson AW, Han S, Dickson M, Holland PC, Crombag HS, Baraban JM. 2008c. Narp mediates extinction of morphine place preference conditions. In Proceedings from the Society for Neuroscience 38th Annual Meeting. San Diego, CA.

Reti IM, Han S, Miskimon M, Rosen JB, Baraban JM. 2009. Nicotine and Delta(9)-tetrahydrocannabinol withdrawal induce Narp in the central nucleus of the amygdala. Synapse 63: 252-255.

Sah P, Faber ESL, De Armentia ML, Power J. 2003. The amygdaloid complex: Anatomy and physiology. Physiol Rev 83: 803-834.

Schlimgen AK, Helms JA, Vogel H, Perin MS. 1995. Neuronal pentraxin, a secreted protein with homology to acute-phase proteins of the immune-system. Neuron 14: 519-526.

Sesack SR, Deutch AY, Roth RH, Bunney BS. 1989. Topographical organization of the efferent projections of the medial prefrontal cortex in the rat: An anterograde tract-tracing study with Phaseolus vulgaris leucoagglutinin. J Comp Neurol 290: 213-242.

Shiflett MW, Balleine BW. 2009. Disconnection of basolateral amygdala and nucleus accumbens dissociates the effects of expected and experienced reward on instrumental performance in rats. Presented at the Society for Neuroscience Conference, October 17th 2009. Chicago, IL.

Tiffany ST. 1990. A cognitive model of drug urges and drug-use behaviorrole of automatic and nonautomatic processes. Psych Rev 97: 147-168.

Tsui CC, Copeland NG, Gilbert DJ, Jenkins NA, Barnes C, Worley PF. 1996. Narp, a novel member of the pentraxin family, promotes neurite outgrowth and is dynamically regulated by neuronal activity. J Neurosci 16: $2463-2478$

Xu DS, Hopf C, Reddy R, Cho RW, Guo LP, Lanahan A, Petralia RS, Wenthold RJ, O'Brien RJ, Worley P. 2003. Narp and NP1 form heterocomplexes that function in developmental and activity-dependent synaptic plasticity. Neuron 39: 513-528.

Yin HH, Ostlund SB, Knowlton BJ, Balleine BW. 2005. The role of the dorsomedial striatum in instrumental conditioning. Eur J Neurosci 22: $513-523$.

Received July 14, 2010; accepted in revised form September 28, 2010. 


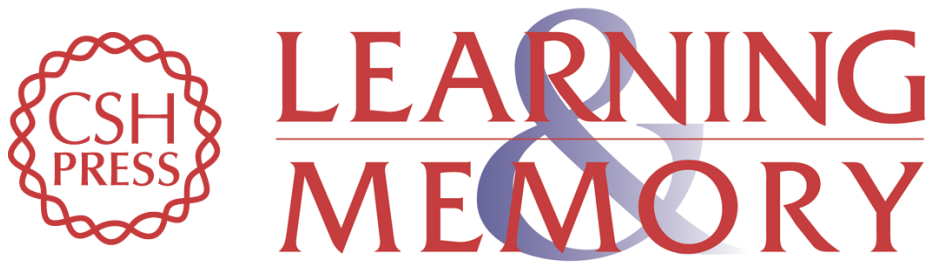

\section{Localized disruption of Narp in medial prefrontal cortex blocks reinforcer devaluation performance}

Alexander W. Johnson, Sungho Han, Ashley M. Blouin, et al.

Learn. Mem. 2010, 17:

Access the most recent version at doi:10.1101//m.1937210

Supplemental
Material http://learnmem.cshlp.org/content/suppl/2010/11/22/17.12.620.DC1

References This article cites 30 articles, 12 of which can be accessed free at: http://learnmem.cshlp.org/content/17/12/620.full.html\#ref-list-1

License

Email Alerting Receive free email alerts when new articles cite this article - sign up in the box at the Service top right corner of the article or click here. 